\title{
The Impact of Political Reforms on Stability in Jordan: (2011-2018)
}

\author{
Aref Humeidi Hussein Bani Hamad \\ Department of Political Science, Amman, Jordan \\ Email: aref_banihamad@yahoo.com
}

How to cite this paper: Bani Hamad, A. H. (2019). The Impact of Political Reforms on Stability in Jordan: (2011-2018). Open Journal of Political Science, 9, 122-144. https://doi.org/10.4236/ojps.2019.91007

Received: November 27, 2018 Accepted: December 26, 2018 Published: December 29, 2018

Copyright $\odot 2019$ by author and Scientific Research Publishing Inc. This work is licensed under the Creative Commons Attribution International License (CC BY 4.0).

http://creativecommons.org/licenses/by/4.0/

\begin{abstract}
This study aimed to identify the relationship between political reform and political stability in Jordan through a quick review of the concepts and indicators of political reform and political stability. The study yielded a number of findings, the most important of which was that Jordan's stability is relative; the process of political reform in the country has made some achievements but that it has not been enough to achieve the desired political stability. The study emphasized that genuine political reform will impact Jordan's stability positively, and when this logic prevails, the situation will change for the better, human rights and freedoms are safeguarded, harmony and justice predominates community, security and stability of the ruler and the ruled alike.
\end{abstract}

\section{Keywords}

Political Reform, Arab Spring, Jordan, Stability

\section{Introduction}

Political stability is considered a purpose and a goal for all countries because it provides the atmosphere and environment necessary for security, development and prosperity. The concept of political stability is a relative concept. Some of its components vary according to societies. This concept was emphasized with the outbreak of the events of the Arab Spring in 2010. There are those who felt that these protests are a kind of political instability, and some who considered it a mere expression of the vitality of society so that the contradictions in it are surfaced. In contrast, the Arab regimes and their political and media institutions used the term "destabilization" to intimidate against any new change. Political stability is not the result of military and security force, but rather the result of political, economic and cultural measures. The nature of the political system in the state determines the extent of political stability in the country. The factors of 
real stability are related to the nature of the relationship between the ruler and his people. Some Arab countries that live in fragile and relative stability exploit the chaotic situation of other Arab states such as Syria, Libya, Iraq, and Yemen to cover the decline in the level of rights and freedoms and to disrupt political reforms (Shaher, 2016).

Political stability in modern countries cannot be achieved by military and security forces while ignoring the legitimate needs and aspirations of the people. Many countries have a large military force and strong security apparatus, but their political stability is fragile and weak. Pakistan, Iraq, Nigeria, and Egypt are among the least stable countries in the world regardless of their huge military spending (Political Stability, 2017). In contrast, there are countries that do not have military strength and powerful security devices, but their stability is solid and hard, and they're capable with their own potential to maintain stability and public security (Mahfouz, 2006). Monaco, New Zeeland, and Singapore are the most stable countries of the world, and those countries are example of countries with more stability and less military forces (Political Stability, 2017).

\section{The Importance of the Study}

The importance of this study is that it deals with the issue of political stability, which is the goal and objective of all political systems, especially in the Arab region, where many countries are experiencing political instability due to the events of the Arab Spring. The importance also stems from studying the relationship between political reforms and political stability. The study will provide the Arab library with contributions in this regard.

\subsection{Research Problem}

The problem of the study lies in the vagueness of the concept of political stability and its complexities and the large number of indicators.

\subsection{Objectives of the Study}

The study aims to examine the nature of the relationship between political stability and political reform, and to shed light on the state of relative stability in Jordan, and the impact of political and constitutional reforms carried out by Jordan after the Arab Spring events on the equation of internal stability.

\subsection{The Hypothesis and Questions of the Study}

The study hypothesis is that the political adjustment of Jordan's political system and its response to the demands of political reform after the Arab Spring events have played a key role in achieving relative stability in Jordan.

In light of this and to answer the hypothesis of the study, the study raises a number of questions:

1) What are the concepts of political stability and political instability?

2) What is the concept of political reform? 
3) What are the political and constitutional reforms undertaken by Jordan after the Arab Spring, and did they contribute to achieving political stability?

\subsection{Methodology of the Study}

The study is based on the analytical descriptive approach, which is defined as the study of political reality, events and phenomena by describing it accurately and applying it to the Jordanian situation and the reforms that took place after the Arab Spring.

\subsection{The Limits of the Study}

Spatial Limits: The Hashemite Kingdom of Jordan, which is located in the Middle East, bordered to the north by Syria, from the west by occupied Palestine, from the south by Saudi Arabia and Egypt and from the east by Iraq.

Time Limits: the study period is: 2011-2018.

\subsection{Concepts of Study}

Political stability means the ability of the political system to manage internal conflicts within the framework of state institutions. political stability could be defined as the degree to which formal roles and structures coincide with a political object, the wider the gap the greater the instability (Eli Margolis, 2010).

Political instability: the inability of the political system to deal successfully with crises, and its inability to adapt to and respond to political changes.

Political reforms: a process of radical and partial modification or development in the form of governance or social relations within the state within the framework of the existing political system and the available means and on the basis of the concept of gradation. In other words, it means developing the efficiency and effectiveness of the political system in its environment, both internally and externally.

Political violence: the actual use of physical force to harm others, in order to achieve political or economic and social objectives with political connotations.

\section{Literature Review}

There are many studies on the subject of political stability, and its association with the political reform. Among the major studies that address the problem of political stability in the Arab Spring countries are the following:

\subsection{Arabic Studies}

1) Choucair' Julia's study (Choucair, 2006) “Illusive Reform, Stubborn Jordanian Stability." The study touched on the political reforms undertaken by Jordan since independence, and that Jordan has succeeded in facing the challenges that threatened the legitimacy of the political system. The study pointed out that the political system is facing great challenges today: the deterioration of the situation on the borders of Jordan, the lack of economic 
success, the decline of the traditional support base system. The study excluded the response of the political system to the demands of democracy.

2) Bani Salameh's study (Bani Salameh, 2013) “Al-Hirāk al-Shabābi al-Urduni fi Zal al-Rabi'a al-'Arabi”. This study aims to identify the political orientations of the Jordanian youth mobility activists in the aftermath of the Arab Spring, by identifying the causes of the emergence of the mobility, the diverse reactions towards it, the speeches, tools, methods, performance, the difficulties and challenges facing this movement, as well as the achievements and its future. The results of the study indicated that economic reasons are the most important factor for the emergence of youth mobility in Jordan. The study showed that the reactions toward mobility were positive, and that the trend towards speeches, tools, methods and performance of the mobility were positive as well, particularly, in the field of peaceful and civilized mobility.

3) Bani Hamad Aref's study (Bani Hamad, 2013) "Political Reforms in Arab Monarchic Regimes (2011-2012)/Jordan and Morocco Case Study". The study reviewed the political and constitutional reforms carried out by Jordan and Morocco after the events of the Arab Spring. The study considered these reforms to be important and in harmony with the conditions of the two countries, but they are not sufficient, and there is a need for further reforms to reach parliamentary governments according to the Western concept.

4) Shateeb Mohammad's study (Miqdad, 2012) “The Impact of Democratic Transformation on Political Stability in Arab Countries". The study touched upon the processes of democratic transformation in the Arab Spring countries. The study pointed out that democracy is not only institutions and procedures, but a political culture that requires a system of values and ideas that promote democracy.

5) Al-Jazzar' Hijazi’s study (Al-Jazzar, 2013) “Economic Factors and the Phenomenon of Political Stability in Kuwait". The study points out that Kuwait is suffering from political instability, especially government instability, due to economic imbalances, uneven distribution of income, and financial and administrative corruption.

6) Al-Khasawneh Anis's study (Al-Khasawneh, 2015) “The Impact of Political Reform in Jordan on Improving the Performance of Government Agencies, A Survey Study." The study examined the impact of political reforms in Jordan on the performance of government agencies after the events of the Arab Spring. The survey found that there is a positive impact on the work of government agencies.

7) Issawi Meithaq's study (Al-Issawi, 2017), “The role of moderation in political stability/Malaysian cultural project as a model". The study concluded that political and religious moderation in its comprehensive concept in Malaysia played a major role in achieving stability and becoming a model for the Islamic world.

8) Al-Ithawi Wissam's study (Al-Ithawi, 2018) “Modernization and stability in 
the Iraqi political system after 2003." The study noted that the process of political modernization in Iraq after 2003, imposed by the United States, did not stem from the Iraqi reality, but came to serve US interests, and it contributed to the instability of the political system in Iraq.

\subsection{Foreign Studies}

1) Oliver Schlumberger and Ande Bank's study (Schlumberger \& Bank, 2002) "Succession, Legitimacy, and Regime Stability in Jordan." The study pointed out that Jordan was one of several countries that witnessed the transfer of power from the late King Hussein to King Abdullah II in a smooth manner, which indicates the political stability in Jordan. The study concluded that during the first three years of his rule, King Abdullah managed to establish a stable system based on political legitimacy, the change of political elites, and individual authoritarian control of power. The study predicted the continuity of authoritarian rule in Jordan during the first twenty years of the 21 st century.

2) Robert Satloff and David Schener's study (Satloff \& Schener, 2015) "Political Instability in Jordan." The study pointed out that Jordan has survived the events of the Arab Spring, but there are many challenges threatening the stability of the Kingdom, and the risk of internal instability is greater than ever, but there is an American interest in maintaining Jordan's stability.

3) Bani Salameh and Ananza's study. (Bani Salameh \& Ananza, 2015) (2016), "Constitutional Reforms in Jordan: A Critical Analysis." This study aims to shed light on the experience of the Jordanian constitutional reforms during the era of King Abdullah II and the Arab Spring. Moreover, this study provides a comprehensive and integrated view of these vital reforms and the democratic process in Jordan. With due consideration to the fact that the constitution represents the backbone of any political regime, constitutional developments in Jordan have been reviewed since the first Jordanian Constitution was drafted in 1928. By analyzing the most recent constitutional amendments, we identify the main features of these amendments as well as their strengths and weaknesses, potential for success or risk of failure, and the positive and negative reactions thereto. This study provides a summary and recommendation, notably, the need for further constitutional amendments to consolidate the process of reform and democracy in Jordan.

4) Bani Salameh's study (Bani Salameh, 2017) (2018), "Political Reform in Jordan: Reality and Aspirations." This study aimed to identify process of political reform under the reign of King Hussein and King Abdullah II. The study also aimed to identify obstacles to political reform in Jordan.A main finding of this study is that political reform in Jordan is an old and popular demand, and that the process of political reform in the country has made some achievements but that it has not been enough to push for real reforms.

5) Bani Salameh and Darawsheh's study (Bani Salameh \& Darawsheh, 2018) 
(2018), "Human Rights in the Jordanian Constitution: Between Theoretical Texts and Practical Application." This study aims to identify human rights in Jordanian constitutions through a quick review of the development of human rights concepts in the world and the journey of the development of Jordanian constitutions. The results of the study showed that the Jordanian constitutions issued in 1928 and 1946 did not contain concepts of human rights as required, nor did they reflect the will of Jordanians looking for political participation, and fundamental freedoms. The 1952 Constitution, which is currently in force, contains a range of civil and political rights for Jordanian citizens. This has been reinforced by a series of legislation regulating the exercise of these rights and duties of the state to ensure the enjoyment of them. However, practice on the ground shows a huge difference between the theoretical texts and the reality of human rights in Jordan. This requires ensuring that the provisions of the Constitution are respected by all authorities as the surest guarantee of respect for human rights

\section{Theoretical Framework}

\subsection{Political Stability}

Political stability is the extent to which the political system is able to invest the conditions and the ability to deal successfully with crises to absorb the conflicts that take place within society, while not using violence, because violence is one of the most important phenomena of political instability.

\subsection{The Concept of Linguistic Political Stability}

Stability means the stability of the thing in place if it is not changed, and stability does not mean immobility.

\subsection{The Concept of Political Stability}

There are two types of political stability:

1) Internal political stability, which means the ability of the political system to manage internal conflicts within the institutions of the state.

2) External political stability, which means the ability of the political system to manage the supreme interests of the state abroad.

There is no defined and comprehensive definition of the concept of political stability as a political term. Nevin Massad defined political stability as a phenomenon characterized by flexibility and proportionality. It refers to the ability of the political system to employ its institutions to make the necessary changes in response to the expectations of the masses and to contain any conflicts that may arise without the use of violence, but only in a narrow range in support of its legitimacy and effectiveness. It is also known as a process of gradual and disciplined change that increases the legitimacy and efficiency of the political process (Khdeirat, 1990). It is also defined as the preservation of order within society and at the same time the ability to adapt to changing situations and events 
(Al-Mashkabah, 2015). The stable political system is also known to be free of various manifestations of violence from demonstrations, assassinations and civil wars (Massad, 1988). Finally, it is defined as a state of security, economic development and social justice in accordance with political legitimacy (Al-Rashwani, 2003).

Through the above definitions of political stability, this concept includes the following elements (Abdellani, 2003).

1) Institutional stability of the state at all levels.

2) The ability of the political system to manage crises and conflicts within society within the framework of the law.

3) The absence of political violence represented by riots, insurgencies, political assassinations, civil wars, and other forms of political violence.

In conclusion, political stability cannot be achieved through military and security force, but through political, social, economic and cultural measures, and the building of a sound political life based on the peaceful transfer of power, popular consent, adherence to the constitution and the rule of law, and the regime's ability to absorb new forces in society without recourse to political violence (Shateeb, 2013).

\subsection{Indicators of Political Stability}

The following are the main indicators of political stability:

1) The pattern of transfer of power in the state: It means the process of changing the person of the head of state, which is different according to the type of political system (royal or republican) and constitutional methods followed. If the transition process occurred according to what is conventionally constitutional, this is a real indicator of the phenomenon of political stability. If it is through coups and military interventions, this is an indication of political instability (Fadhel, 2010).

2) Institutionalism: it means that political decision-making in a society is governed by institutional mechanisms that take the system of separation of powers, respect for the rule of law and the exclusion from the personalization of the decision-making process, and the more institutionalized it is reflects positively on political stability (Bani Salameh \& Al-Sharah, 2011).

3) The legitimacy of the political system: The legitimacy of the political system is one of the basic pillars of political stability, and political stability is in turn a sign of political legitimacy. Political legitimacy is defined as: "the justification of the ruling authority from the logic of collective will." This legitimacy is manifested by the people's acceptance of the regime and submission to it voluntarily. Maurice Defrague defines political legitimacy as the political system's acceptance of popular consensus and thus means acceptance and public satisfaction with the ruling regime (Hussein, 2015).

Max Weber identified the sources of political legitimacy as the traditional, religious and historical legitimacy, charismatic legitimacy (personal leader), and 
legal legitimacy based on the constitution and the law (Weber, 2011).

4) The power of the political system and its ability to protect society and state sovereignty: The strength of the political system is an important indicator of the phenomenon of political stability. A regime that cannot avoid the landslides and sudden fluctuations that may overthrow it, and whose infrastructure will open the door to instability, and that the system, which does not satisfy the aspirations of citizens will lead to political instability (Sulaiman, 2009).

5) Limited change in the positions of political leaders: The limited change in the political leadership of the executive branch; the survival of political leaders at the head of any political system for a long time is indicator of political stability, but it must be coupled with the consent of the people. The successive change in leadership positions and in government is one of the major indications of political instability (Davargier, 2009).

6) Parliamentary stability: Parliament represents the legislative authority and is the representative of the people in all systems of different types (presidential, parliamentary, and mixed). The executive or the head of state cannot dissolve the parliament, as the source of legitimacy of parliament is the people through the election, but sometimes there are patterns of instability for parliament:

a) Resignation or termination of membership of one or more members of Parliament.

b) Dissolution of the Parliament before the completion of its legal period (Bani Salameh \& Al-Sharah, 2011).

7) Political Participation: Political participation is one of the indicators of political stability. According to Samuel Huntington: the activities of ordinary citizens are designed to influence government decision-making, in which individuals have official channels to express their views on national issues and the selection of deputies and representatives in the parliamentary and local councils. Public participation thus becomes a means of achieving internal stability and strengthening the legitimacy of political power (Bani Salameh, 2013).

8) The absence of political violence is one of the indicators of political stability; political violence includes: civil wars, secessionist movements, rebellion, military coups, riots, demonstrations and strikes. Political violence can be defined as: "the actual use of physical force to harm others, in order to achieve political goals or economic and social objectives that have political implications" (O'Neill, 2012). The violence may be formal or informal. The formal is directed by the regime against citizens or against certain groups, organizations or elements, while the informal is directed by citizens or groups against the regime and some of its symbols. Separatist movements, rebellions and civil wars are the highest forms of political instability, including the widespread use of violence (Bani Salameh \& Al-Sharah, 2011).

9) National unity and the disappearance of sub-loyalties: The way the political 
system deals with social pluralism (ethnic, religious, national and linguistic affiliations) contributes to political stability. If all are dealt with in accordance with the principle of legal citizenship, rights and duties, Thus political stability is achieved and vice versa (Shaher, 2016).

10)The success of economic policies: Economic stability is seen as a general indicator of political stability in all societies. When the political system is stable, it directs its economic policies towards development goals, and these development policies that raise the standard of living and welfare of individuals and create some reassurance and popular satisfaction with the political system (Al-Ithawi, 2018).

11)The effectiveness and efficiency of the political system: The ability of the political system to respond to the requirements of the internal and external environments, through the good use of resources available to meet internal demands (Al-Serhan et al., 2017a).

12) The flow of internal and external migration: The causes of migration both internally and externally can be summed up by the security and economic situation, both of which indicate a phenomenon of political instability, and the low or moderate migration rates indicate political stability. Sometimes migrant workers may be a cause of political instability in host countries.

13)The rule of law: It means that legal and constitutional rules are above the will of all, governors and the governed, and the inability of the political system to apply the law is an indicator of the regime's instability (Bani Salameh et al., 2018).

\subsection{Political Instability}

Political instability is the most common political phenomenon in developing countries, and may include: government and parliamentary instability, instability of the political system (from monarchy to the republic, from civil rule to military rule), political violence including: riots, demonstrations, disturbances, political assassinations, civil wars and separatist movements (Al-Ithawi, 2018).

\subsection{The Concept of Political Instability}

The concept of political instability is a social phenomenon that refers to the absence of stability and security. There are several definitions of this concept, most notably:

- Samuel Huntington argues that instability is equal to political demands divided by political institutions. In other words, instability increases as political demands increase, and the ability of political institutions to respond effectively to them has been weakened (Al-Serhan et al., 2017a).

- Political instability is the most common political phenomenon in developing countries, and may include: government and parliamentary instability, instability of the political system (from monarchy to the republic, from civil rule to military rule), political violence from riots, demonstrations, disturbances 
and political assassinations Civil wars and separatist movements (Al-Serhan et al., 2017b).

\subsection{Indicators of Political Instability}

The increase in the index of political violence is one of the most important indicators of political instability, and when these indicators increase significantly, the state is moving towards political instability. The degree of political violence depends on several factors, the most important of which are (Al-Ithawi, 2018):

- The scope of violence: the degree of participation in political violence within the state.

- Severity of violence: any damage and vandalism caused by violence.

- The persistence of violence: the time taken by political violence.

The following are the main indicators of internal political instability, (Jassem, 2010):

1) The number of political assassinations within the state.

2) THE number of general strikes.

3) The existence of guerrilla warfare.

4) The number of government crises within political construction.

5) The number of purges carried out in the apparatuses of the state.

6) The number of riots within the state system.

7) The number of revolutions that broke out within the state.

8) The number of anti-government demonstrations.

9) The number of people killed in all forms of domestic violence.

10) The relationship between the military and political establishment.

11) The number of terrorist operations.

12) The number of charges of torture by the security services.

Indicators of external conflict that contribute to instability are:

1) The number of demonstrations against the foreign policy of the state.

2) The number of protests against the foreign policy of the state.

3) The number of times the sanctions imposed on the State.

4) The number of States that have severed diplomatic relations with the state.

5) The number of times the ambassadors of the State have been summoned or the expulsion of foreign ambassadors.

6) The number of times threats have been issued against the State.

7) The number of times in which military action was used to solve the problems of the State externally.

8) The number of wars in which the State participated.

9) The number of times military forces were moved without reaching the point of war.

10) The number of charges against the State.

11)Death toll in external conflicts.

\subsection{The Concept of Political Reform}

Political reform is mentioned in the Holy Quran in more than one Surat ((God 
knows the spoiler from the reformer)) (Surah Al-Qasas). And the Almighty said to Pharaoh ((If you want to be a mighty in the land and you do not want to be among reformers)) (Al-Baqarah).

As a concept and a political term, there is overlap, similarity and confusion between the concept of political reform, political development, political modernization and political change. These concepts reflect the transformation, change and the sustainable movement forward, which is reflected in the structure of the political system. There are several definitions of political reform, most notably:

- Mohammed Bani Salameh defines political reform as: Change and adjustment to the best for an abnormal or bad situation, especially in the practices and behaviors of corrupt or authoritarian institutions or backward societies, removal of injustice, correction of a mistake or correction of a distortion (Bani Salameh, 2017).

- Amin Mashaqbeh defines the political reform as a process of radical and partial change in the form of governance or social relations within the state within the framework of the existing political system and the available means and on the basis of the concept of gradualism. In other words, it means developing the efficiency and effectiveness of the political system in its environment, both internally and externally (Mahakaba \& Al-Mutasim, 2010).

The most important mechanisms and components of political reform are: constitutional and legal amendments, structural changes in institutions, and modification of the prevailing system of values (Arabic, 2013).

The political reform must be self-imposed from the inside and not imposed from the outside. It has a comprehensive character that carries the character of continuity and realistically stems from the reality of the state and the nature of the existing imbalances that need to be reformed, and the gradualism should be reversed step by step and not quick and surprising. Its essence is not formal, and must be in line with the existing intellectual structures in the sense that they are absorbed both privately and publicly, not to mention the importance of transparency and clarity and not be ambiguous or jump into the unknown. As the political stability factor, which means legal transition from one case to another, is fundamentally linked to the concept of political legitimacy, which means that the values of the political system correspond to those of the people. Otherwise, there is no point in reform when it leads to a decline in political legitimacy (Bani Salameh \& El-Edwan, 2016).

Political reform is important for the stability of any political system that wants to survive, because of its direct relationship with political adaptation and the absorption of political and social variables. This is the opposite of stagnation. The rigid regimes that cannot adapt produce political and economic stalemate (Bani Salameh \& Al-Sharah, 2011).

\section{Political Stability in Jordan}

Since the establishment of the Emirate in 1921, Jordan has not witnessed full po- 
litical stability in terms of indicators and manifestations, but rather relative stability due to the political, security, social and economic developments, and events in the region. This has prevented Jordan from reaching a stage of full political stability. The country has suffered many regional crises as a result of Arab-Arab conflicts, the Arab-Israeli conflict and foreign interference in the Arab region, of which Jordan was a major party because of historical, geographic and social factors (Kharboush, 2014). Jordan was influenced by these crises and interacted with them, even if it was not willing to do so. Jordan is among five countries that have the highest human, economic and military capabilities, four of which are Arab countries, namely Iraq, Syria, Saudi Arabia, Egypt, and the fifth is Israel. Therefore, it is burdened with problems, which exceed the burden of its normal size or expenditure on which it has a responsibility to meet, or the local, regional and international demands that Jordan must meet. All of this exceeds the resources available to Jordan to respond to these burdens, demands and expenses. In addition to the outbreak of the events of the Arab Spring in 2010 (Bani Salameh, 2017).

\subsection{Factors of Political Stability in Jordan}

Jordan has maintained its relative stability since the establishment of the emirate in 1921, and has shown considerable resilience as a political entity, despite its presence in an unstable region full of conflicts and crises, and despite limited natural resources (Khataybeh \& Bani Salameh, 2014). Several internal and external factors contributed to political internal stability:

\subsection{Internal Factors}

A number of internal factors contributed to achieving relative stability in Jordan, notably (Bani Salameh \& Mashgbeh, 2018):

1) Religious and historical legitimacy of the Hashemite leadership.

2) The existence of constitutional and legal structures and institutions.

3) The high degree of political adaptation of the regime and the implementation of gradual political reforms since the emergence of the state.

4) The cohesion of the military and security establishment, and the centrality of the political system during crises.

5) The state of social harmony.

6) Increasing degree of political awareness among citizens (Bani Salameh \& El-Edwan, 2016).

\subsection{External Factors}

The external factors have played a major role in achieving internal stability in Jordan. Since the establishment of the emirate, Jordan has enjoyed British political, military, and economic support. The United States then assumed this role. The Jordanian leadership succeeded in persuading many external parties that Jordan's survival and stability is a necessity for regional security. Jordan also re- 
ceived financial and economic support from the Arab countries, especially the Gulf, all of which contributed to the relative stability in Jordan (Muasher \& Ottaway, 2011).

\subsection{Factors of Instability in Jordan}

There are factors contributing to the relative instability in Jordan, notably (Bani Hamad, 2013):

1) Jordan's geographic location in area full of conflicts and crises.

2) Jordan's organic association with the Palestinian cause, and Jordan's fear of Israeli and American projects to solve the Palestinian issue at the expense of Jordan; the latest of which is called the deal of the century (Bani Salameh \& El-Edwan, 2016).

3) The instability in the neighboring countries, especially Iraq and Syria and foreign interference.

4) The refugee crisis in Jordan as a result of the crises in the region: Palestinian, Iraqi, and Syrian asylum, which constitutes security, economic and social burdens.

5) The threat of terrorism and radicalism coming from neighboring countries (Syria and Iraq) (Khataybeh \& Bani Salameh, 2014).

6) The crippling economic crisis in Jordan: the budget deficit, the rise in internal and external public debt, the rise in the unemployment rate especially among university graduates, the increase in poverty rates and the decline in the standard of living of citizens, the spread of financial and administrative corruption.

7) The preoccupation of Arab states with their internal problems and the decline of Arab solidarity (Bani Salameh \& Al-Sharah, 2011).

\section{Political Reforms in Jordan}

Since 2010, Jordan has faced internal difficulties and external challenges, most notably the events of the Arab Spring, which began in Tunisia in 2010 and moved to a number of other Arab countries (Egypt, Libya, Syria, Yemen, Jordan, Morocco, Bahrain and Oman). The protesters demanded the overthrow of republican regimes, while in the royal regimes it was demanding reform of the regimes (Bani Salameh, 2017). In the beginning, the events of the Arab Spring targeted Arab republican regimes, in which the citizen suffered from tyranny, corruption, repression of freedoms and assault on the dignity of the people. These events succeeded in bringing down the regimes of Tunisia, Egypt, Libya, Yemen, The Syrian crisis has been internationalized. The events of the Arab Spring moved to some Arab monarchies (Jordan, Morocco, Oman and Bahrain) in 2011 in the form of popular protests and movements calling for reform of these regimes through political and constitutional reforms that restore balance between the three authorities, and solving the problem of unemployment and poverty, and achieving equal opportunities and social justice (Hamouri, 2012). 
Several factors have contributed to avoiding the fate of some of the republican regimes. The most prominent of these are: -Royal regimes are accepted by citizens and were not bloody and based on historical, religious and tribal legitimacy, flexibility and non-recourse to the security solution in dealing with the demands of popular movements, either through political reforms (Jordan and Morocco), or through provision of financial rewards to appease their own citizens (rich Gulf states), except for Bahrain, which suppressed the protests by force using the island's shield forces because of the nature of sectarian protests and Iran's intervention in the crisis (Bani Salameh, 2013).

The worsening in economic conditions (high indebtedness, inflation, unemployment, low living standards, rising prices of basic commodities and fuel, and the spread of financial and administrative corruption, and the lack of equality of opportunity, and social justice) all contributed to the arrival of the Arab Spring in Jordan. The Jordanian popular movement began in 2011, calling for a number of political, economic and social reforms and combating financial and administrative corruption, and then slogans evolved to demand constitutional reforms and return to the Constitution of 1952, to strengthen the role of the House of Representatives by strengthening the separation of powers, in order to prevent the executive from turning to other legislative and judicial authorities. The slogans that demand reform of the political system in Jordan have risen to the application of constitutional monarchy on the basis that the Jordanian regime, in accordance with the 1952 Constitution, is a royal monarchy (Bani Salameh \& Ananza, 2015).

In light of the events of the Jordanian Spring, the political system responded to the demands of the popular movements for political and constitutional reforms in connection with Jordan's internal and regional circumstances. The political and constitutional reforms were completed in two years (2011 and 2012). Jordan adopted a gradual approach to achieve this. (42) Amendments to the provisions of the Jordanian Constitution, the most important of which are the establishment of the Independent Electoral Commission and the Constitutional Court, the amendment of articles relating to the empowerment and protection of freedoms, the reduction of the jurisdiction of the State Security Court, In addition to providing constitutional guarantees for the dissolution of the House of Representatives, represented in the resignation of the government that attributes the dissolution of the Council within a week of the date of resolution, and the establishment of the principle of separation of powers (Report of the National Dialogue Committee, 2011).

At the beginning, there was a slow response to the popular demands, which led the king to take the initiative to lead the comprehensive reform process in Jordan, (Nassraween, 2011). The government was instructed on 14/3/2011 to form the national dialogue committee headed by Tahir al-Masri, then chairman of the Senate, as well as the formation of a Royal Committee to review the Constitution headed by Ahmed Lozi on 26/4/2012 to conduct a comprehensive re- 
view of the constitutional provisions of the 1952 Constitution to promote political life in a constitutional context, to promote institutional political action and to promote Jordan's democratic process, and achieve comprehensive reform in its political, economic and social dimensions (Al-Mashkaba, 2012).

The constitutional amendments were adopted on 30/9/2011 (Bani Salameh \& Ananza, 2015). The following are the most prominent achievements in the political and democratic dimension of these amendments:

\subsection{First: To Promote Balance between the Three Authorities}

As the balance between the three authorities is viewed as major step towards promoting and consolidating the democratic process. This process is reflected positively in the political, economical, social, and cultural fields. The balance between the three authorities also lays down the foundation for comprehensive and sustainable development, i.e., establishing the rule of law, institutions, rights, and justice, as well as the establishment of justice and equality in the community which respects human dignity and human rights.

\subsection{Legislature}

The constitutional amendments in 2011 ended the situation of the executive branch's sway over the legislative and strengthened the role of the legislative authority to achieve the principle of balance between the authorities as follows (Hamouri, 2012):

- The establishment of an independent body that supervises and manages the parliamentary electoral process at all stages and supervises any other elections decided by the Council of Ministers. The right of candidates to observe the electoral process and to punish the abusers was confirmed by the will of the electorate, thus achieving further guarantees for the holding of free, fair and transparent elections without the intervention of any party (Bani Salameh \& Ananza, 2015).

- The text that the government, which dissolves the House of Representatives in its time, resigns within a week of the date of the dissolution and may not be assigned to the formation of the next government. It was also stressed that if the dissolution of the House of Representatives for some reason, it is not permissible to dissolve the new Council for the same reason, and this amendment achieves a balance between the executive and legislative authorities (Bani Salameh \& Ananza, 2015).

- The duration of the regular session is six months instead of four, for reasons of raising the efficiency and speed of completion in the legislative process.

- Confirmation of the right of the House of Representatives to refer the Ministers to the Public Prosecution, with the reasons for that being justified. The decision to refer shall not pass without the agreement of a majority of the members of the House of Representatives. The Minister, who is accused by the Public Prosecution, shall be dismissed from duty following the decision 
of the House of Representatives, and his resignation doesn't prevent his prosecution or continuation of his trial (Bani Salameh \& Ananza, 2015).

- Obligation of the Government if the House of Representatives is not held to submit its Ministerial Statement and to request confidence in that statement within one month from the date of the meeting of the new Council. Thus preventing the government from taking the speech of the throne as a Ministerial Statement and achieving the democratic principle for the purposes of granting confidence and for the purposes of monitoring and parliamentary accountability.

- The provision of holding parliamentary elections within four months from the date of the dissolution confirms that the state may not remain without a parliamentary council for more than four months. Thus, the postponing of elections is no longer possible and the elections cannot be postponed year after year. Thus, the king's powers to delay the elections have been limited to a general postponement, so that it is now inevitable to hold parliamentary elections within four months of the date of dissolution (Bani Salameh \& Ananza, 2015).

- Strengthen the House of Representatives on the vote of confidence on the new government, where it should get half plus one, which means (76) votes in favor at the present time, while in the past to avoid voting against them (76) votes, regardless of the number that votes with the government.

- Immunization of the parliamentary majority of the minority dictatorship by reducing the number of members of the House of Representatives present in the parliamentary sessions from two thirds to one half plus one, and thus removed the disabled one third.

- Involve the Senate and the House of Representatives by monitoring the work of the government by requiring the Audit Bureau to submit a report to the two chambers, including violations committed by the government, at the start of each regular session, or whenever one of the two chambers so requests.

- Present budgets of government units to the Senate and House of Representatives for discussion and approval, as is the case with the state budget (Bani Salameh \& Ananza, 2015).

\subsection{Executive Authority}

The Jordanian Constitution of 1952 and its amendments for 2011 indicate that the executive authority shall be vested in the King and shall be governed by its Ministers in accordance with the provisions of this Constitution.

- Emphasizing the general mandate of the Council of Ministers on all the affairs of the State, and the inadmissibility of delegating any of the powers and tasks of the Council of Ministers under the law (ordinary legislation) and restricting them to the provisions of the Constitution only, in view of the importance of limiting the general jurisdiction over the affairs of the State to the 
Council of Ministers and to avoid abuse of laws, and the leniency in issuing violations in a way that contravenes the general principle of the mandate of the Council of Ministers and to ensure the limitation of responsibilities and the definition of accountability. As well as to prevent certain departments or institutions from turning to the constitutional mandate holder (Bani Salameh \& Ananza, 2015).

- Determining the validity of the Council of Ministers (in case the National Assembly is not held or dissolved with the approval of the King to issue provisional laws in the following cases: General disasters, state of war and emergency, the need for urgent expenses that cannot be deferred. This would largely prevent the Executive from taking over the legislature, and these provisional laws should be presented to the National Assembly at its first meeting. It is noted that the executive authority was restricted to issuing temporary laws only when the National Assembly was dissolved, and not as in the past when it authorized the executive authority to issue provisional laws when the Council was dissolved or not held.

Restricting the powers of the king in the dismissal of the government, when it explicitly stated that upon the death of the prime minister, all ministers are considered to be resigned, which was not included in the Jordanian constitution before the amendment (Bani Salameh \& Ananza, 2015).

\subsection{Judiciary}

The constitutional amendments reinforced the independence of the judiciary as follows (Edwan et al., 2018):

- The decisive emphasis on the independence of the judiciary.

- The restoration of the judiciary to its authority by providing for the trial of ministers for the crimes attributed to them in the performance of their functions before the competent courts in the capital, thus eliminating discrimination or exclusion from the rule of universal jurisdiction of the judiciary on all citizens.

- The provision that the judiciary has the right to adjudicate the validity of the members of the House of Representatives, which thus abolished the competence of the Council of Representatives in the appeals against its members (Bani Salameh, 2017).

- Provide for the establishment of the Judicial Council that shall assume all matters relating to the regular judges and shall have the right to appoint regular judges without interference from any authority. This entrenches the independence of the judiciary.

- Canceling the Supreme Court of Justice and replacing it with a two-degree administrative judiciary. This promotes the citizen's right to challenge decisions before the courts on two levels, and the administrative courts must be established in two degrees to ensure the greatest degree of justice and in accordance with international standards (Bani Salameh, 2017). 


\subsection{Establishment of a Constitutional Court}

The establishment of a constitutional court to serve as an independent judicial body. It shall consist of nine members appointed by the King. It shall supervise the constitutionality of the laws and regulations in force and issue its rulings in the name of the King, and its provisions shall be final and binding on all authorities. The Court shall have the right to interpret the provisions of the Constitution if it is so requested by a decision of the Council of Ministers or by a decision taken by one of the two Houses of Parliament by majority. The Senate, the House of Representatives and the Council of Ministers shall have the right to appeal directly to the Constitutional Court on the constitutionality of the laws and regulations in force.

The establishment of the Constitutional Court is a very important transformation towards the application of democracy in a manner consistent with international standards, ensuring the preservation of the principles of legality and separation of powers and preventing any encroachment upon any other authority or on citizens. The Jordanian constitution issued in 1952, before the last constitutional amendments in 2011, was not subject to the issue of monitoring the constitutionality of the laws. The provisions of this law are void of any provision in this regard. The Jordanian judiciary did not explicitly grant this right nor prevent it from doing so in the Basic Law of 1928 (Bani Salameh, 2017).

\subsection{Freedom of Information and the Press}

Strengthening the fourth authority, the press and the media by stressing the state's guarantee of freedom of the press, printing and publishing within the limits of the law, and the impossibility of disrupting newspapers and the media and not revoking its license except by judicial order. The censorship of the press and the media was also restricted during the declaration of martial law or emergency (Bani Salameh \& Darawsheh, 2018).

\subsection{Freedoms, General Rights and Human Rights}

- Emphasize the preservation of the family entity and the protection of motherhood, childhood, aging and people with disabilities.

- Emphasize that any attack on public rights and freedoms or the inviolability of private life of Jordanians is a crime punishable by law (Bani Salameh \& Darawsheh, 2018).

- Emphasize the treatment of all who are arrested, or imprisoned in a manner that protects human dignity. It is not permissible to torture the arrested.

Emphasize that the laws promulgated under this Constitution to regulate the rights and freedoms may not affect the essence or the basis of these rights emergency (Bani Salameh \& Darawsheh, 2018).

\section{Constitutional Amendments (2014 and 2016)}

New constitutional amendments were made in 2014 and 2016, which included: 
- Extend the powers of the Independent Electoral Commission to include the parliamentary and municipal elections and any other elections as mandated by the Council of Ministers. Expanding the powers of the King by appointing the following parties without the approval of the Council of Ministers: Crown Prince, Deputy King, President and Members of the Senate, President and Members of the Constitutional Court, President and members of the Judicial Council, Army Commander, Director of Intelligence and Director of Gendarmerie.

Despite the importance of these reforms in Jordan, but they are not enough, from the point of view of some political forces and movements, as they did not touch the essence of the broad powers enjoyed by the King and did not reach a real parliamentary government, as the king still has vast constitutional powers, and the demands of the people are still for further reforms, through the continuation of their protest activities from time to time and their demand for genuine political and constitutional reforms that restore power to the people through the development of a more representative election law and the promotion of democratic life, and the abolition of the Senate or its election, and necessity of a text in the Constitution that obliges the king to mandate the head of the majority party, which leads the legislative elections or the head of the largest bloc in the House of Representatives to form a government, which leads to a real parliamentary government, and the king later issued his vision on political and constitutional reforms in the discussion papers, but it has not found its way to application so far (Bani Salameh, 2017).

\section{Conclusion}

At the end of this study, it can be concluded that there was a strong correlation between political reform and political stability in Jordan. The study pointed out that despite the importance of these reforms in Jordan, they are not enough, from the point of view of some political forces and movements, as they did not touch the essence of the broad powers enjoyed by the King and did not reach a real parliamentary government, as the king still has vast constitutional powers, and the demands of the people are still for further reforms, through the continuation of their protest activities from time to time and their demand for genuine political and constitutional reforms that restore power to the people through the development of a more representative election law and the promotion of democratic.

In conclusion, it must be emphasized that genuine political reform will impact Jordan's stability positively, and when this logic prevails, the situation will change for the better, human rights and freedoms are safeguarded, harmony and justice predominates community, security and stability of the ruler and the ruled alike, and this is the duty of the faithful patriots in this country, and those who care about their people, security, and the country's future. It is without any doubt, that modern Jordan cannot be built, and it cannot ensure the future gen- 
erations, or achieve political stability.

\section{Recommendations of the Study}

Jordan's triumph over its crisis requires that reform be considered a historical necessity and a national interest in order to restore trust among the people, the leadership, and state institutions. This requires adopting a comprehensive national strategy for political, economic, administrative, and moral reform in order to bring about the required changes in the state and society through the following:

- Comprehensive political reform is ultimately aimed at reaching a stable modern democratic state in which the rule is based on a genuine constitutional, legal and popular legitimacy, and political, social and economic stability requires the formulation of a new social contract based on a modern state that's based on constitutional and institutional foundations.

- Jordan should proceed without further hesitation to undertake further political and constitutional reforms to fortify the King and make it a rule among the authorities, and to remove the distortions of the 1952 Constitution to restore balance and separation between the three authorities and to broaden the base of popular participation, and the implementation of a more representative electoral law acceptable to the majority of political and partisan forces and popular movements, in preparation for reaching real parliamentary governments.

\section{Limitations and Future Directions}

One of the acknowledged limitations of this study it focused on the relationship between political reform and political stability, however, for a more comprehensive understanding of how to achieve political stability, this research needs to be broadened to include the impact of other factors on political stability such as economic reform, the role of foreign aid and so on.

Therefore, future work is needed to explore in detail the impact of other factors on political stability in Jordan. Other potentially areas for future research that emerged from the study are the following:

- The impact of economic reform.

- The role of foreign aid.

- Investigating the role of regional environment.

- The Researcher intends to build on the findings of this article to study one or more of the previous themes.

\section{Conflicts of Interest}

The author declares no conflicts of interest regarding the publication of this paper.

\section{References}

Abdellani, A. K. (2003). Political Opposition and the Democratic Transition in Morocco 
(pp. 34-35). Unpublished Doctoral Dissertation, Cairo: Cairo University.

Al-Baqarah, verse 220.

Al-Issawi, M. (2017). The Role of Moderation in Political Stability/the Malaysian Cultural Project Model. Karbala: Center for Strategic Studies, University of Karbala.

Al-Ithawi, W. (2018). Modernization and Stability in the Iraqi Political System after 2003. Berlin: Arab Democratic Center for Strategic, Political and Economic Studies, I.

Al-Jazzar, H. (2013). Economic Factors and the Phenomenon of Political Stability in Kuwait. Arab Economic Research Magazine, No. 63-64.

Al-Khasawneh, A. (2015). The Impact of Political Reform in Jordan on Improving the Performance of Government Agencies: An Exploratory Study. Jordanian Journal of Business Administration, 11, 15-35.

Al-Mashkaba, A. (2012). The Jordanian Political System (p. 50). Amman: Al-Dustour Commercial Printing Press.

Al-Mashkabah, A. (2015). The Brief in Political Concepts and Terms, Amman, Jordan.

Al-Rashwani, M. (2003). Structural Adjustment and Political Stability in Jordan. Abu Dhabi: Emirates Center for Research and Strategic Studies.

Al-Serhan, S. F. et al. (2017a). Challenges Facing National Security in the Arab Gulf States: A Case Study of Bahrain. International Journal of Humanities and Social Science, 7, 131-142.

Al-Serhan, S. F., Bani Salameh, M. T., Akhu Rsheideh, H. A., \& Mashagbeh, A. A. (2017b). The European Policies towards the Problem of Migration from the Arab Spring Countries. British Journal of Humanities and Social Sciences, 18, 48-62.

Arabic, M. P. (2013). An Attempt to Root out the Concept of Political Reform. Journal of Politics and Law, No. 9, 9-18.

Bani Hamad, A. (2013). Political Reforms in Arab Property Systems (2011-2012)/Jordan and Morocco Case Study. Unpublished Master Thesis, Amman: University of Jordan.

Bani Salameh, M. T. (2013). Al-Hirāk al-Shabābi al-Urduni fi Zal al-Rabi’a al-'Arabi, markis al badeel.

Bani Salameh, M. T. (2017). Political Reform in Jordan: Reality and Aspirations. World Affairs Journal, 180, 47-78. https://doi.org/10.1177\%2F0043820018765373

Bani Salameh, M. T., \& Al-Sharah, M. K. (2011). Kuwait's Democratic Experiment: Roots, Reality, Characteristics, Challenges, and the Prospects for the Future. Journal of Middle Eastern and Islamic Studies, 5, 57-81. (In Asia) https://doi.org/10.1080/19370679.2011.12023185

Bani Salameh, M. T., \& Ananza, A. (2015). Constitutional Reforms in Jordan: A Critical Analysis. Digest of Middle East Studies, 24, 139-1160. https://doi.org/10.1111/dome.12068

Bani Salameh, M. T., \& Darawsheh, S. (2018). Human Rights in the Jordanian Constitution: Between Theoretical Texts and Practical Application. International Journal of Human Rights and Constitutional Studies, 6, 70-88. https://doi.org/10.1504/IJHRCS.2018.091658

Bani Salameh, M. T., \& El-Edwan, K. I. (2016). The Identity Crisis in Jordan: Historical Pathways and Contemporary Debates. Nationalities Papers, 44, 985-1002. https://doi.org/10.1080/00905992.2016.1231454

Bani Salameh, M. T., \& Mashgbeh, A. (2018). The American Russian Rivalry in the Middle East. International Journal of Humanities and Social Sciences, 8, 28-35.

Bani Salameh, M., Ananzah, A., \& Daradkah, M. (2018). The Impact of Economic Reform 
on Political Reform: Jordan as a Model. American Journal of Industrial and Business Management, 12, 1556-1586. https://doi.org/10.4236/ajibm.2018.86105

Choucair, J. (2006). Illusive Reform, Stubborn Jordanian Stability. Washington DC: Carnegie Yessell International Center.

Davargier, M. (2009). Introduction to Political Science I (Translated, Aldroubi, S. and Atassi, J.). Syria: Damascus Publishing House.

Edwan, K. et al. (2018). Elite Circulation: Case Study of the Jordanian Parliament: 1989-2016. Dirasat: Human and Social Sciences, 45, 253-247.

Eli Margolis, J. (2010). Understanding Political Stability and Instability. Journal Civil Wars, 12, 326-345. https://doi.org/10.1080/13698249.2010.509568

Fadhel, S. (2010). Political Stability in Developing Countries. Journal of the Gulf Views, No. $73,76$.

Hamouri, M. (2012). Working Paper on Constitutional Amendments in Jordan. In Proceedings of the Jordanian Constitution Conference in 60 Years (pp. 13-25). Amman: University of Jordan.

Hussein, U. (2015). Political Sociology, Contemporary Study (p. 192). Baghdad: Al-Yamamah for Printing and Publishing.

Jassem, M. (2010). The Compromise Distribution of Authorities and Its Impact on Political Stability in Iraq. Baqubah: Diyala University.

Kharboush, M. S. El. D. (2014). Challenges Facing Jordan. Giza: Arab Center for Research and Studies.

Khataybeh, Y., \& Salameh, M. B. (2014). Factors and Manifestations of the Ideological Extremism as Realized by Youth in Jordanian Universities: An Empirical Sociological Study. Journal of Social Sciences, 42, 3-45.

Khdeirat, O. (1990). The Middle Class and Its Impact on Political Stability in Jordan. Journal of Arab and International Studies, No. 38, 71.

Mahakaba, A., \& Al-Mutasim, B. (2010). Political Reform and Good Governance (a Theoretical Framework) (pp. 28-30). Amman: Al-Safir Press.

Mahfouz, M. (2006). In the Meaning of Political Stability. Riyadh Newspaper, No. 13819, Saudi Arabia.

Massad, N. (1988). Minorities and Political Stability in the Arab World. Cairo: Center for Political Research and Studies.

Miqdad, M. (2012). Reform Calls in Jordan and the Problem of the Relationship with Government Policies and Indicators of Political and Economic Stability, An Analytical Study (2001-2010). Journal of the Union of Arab Universities for Literature, 2, 93-112.

Muasher, M., \& Ottaway, M. (2011). The Arab Monarchies: An Opportunity for Reform Not Yet Achieved, Carnegie Endowment for International Peace Papers, United States.

Nassraween, L. (2011). A Series of Articles in the Jordanian Newspaper Al-Arab Al-Youm $18-20-29 / 8$.

O’Neill, P. (2012). The Principles of Comparative Political Science I (Translated, Jbaili, B.). Damascus: Dar al-Farqad for Printing, Publishing and Distribution.

Political Stability (2017). Country Rankings.

https://www.theglobaleconomy.com/rankings/wb-political

Report of the National Dialogue Committee (2011).

Satloff, R., \& Schener, D. (2015). Political Instability in Jordan. New York: Council on Foreign Relations.

Schlumberger, O., \& Bank, A. (2002). Succession, Legitimacy, and Regime Stability in 
Jordan. The Arab Studies Journal, 9-10, 50-72.

Shaher, A. (2016). Political Stability, Standards and Indicators. Syria: National Center for Research and Studies, University of Damascus.

Shateeb, M. (2013). The Impact of Democratic Transformation on Political Stability in the Arab Countries, Center for Regional Studies. Regional Studies, 9, 167-180.

Sulaiman, R. (2009). Political Stability and Indicators. Journal of Urban Dialogue, 3, 34-56.

Weber, M. (2011). Science and Politics as a Craft (p. 263, Translated, Ketura, G.). Beirut: Arab Organization for Translation. 